\title{
Optimization of Test Parameters that Influence on Dry Sliding Wear Performance of Steel Embedded Glass/Epoxy Hybrid Composites by Using the Taguchi Approach
}

\author{
G.R. Chavhan ${ }^{a}, *$, L.N. Wankhadeb \\ a Mechanical Engineering Department, SGGS, IE \& T, Nanded, M.S., India, \\ bProduction Engineering Department, SGGS, IE \& T, Nanded, M.S., India.
}

Keywords:

Steel embedded hybrid composites Sliding wear

Taguchi

Surface morphology

ANOVA

* Corresponding author:

Ganesh R. Chavhan

Email: ganeshchavhan007@gmail.com

Received: 25 March 2020

Revised: 6 July 2020

Accepted: 14 September 2020

\section{A B S T R A C T}

In the present study, the tribological performance of steel embedded $E$ glass fiber/epoxy (SGFPC) was studied with the help of the pin/ball on disc wear testing machine. The specific wear rate (SWR) and the average coefficient of friction ( $\mathrm{CoF}$ ) were investigated. The parameters based on process parameters and material composition such as steel volume \%, sliding distance, and applied load is identified, which are affecting the wear of composite samples. The design of experiments was planned with the help of the Taguchi technique and L27 Orthogonal Array was used. Composites were fabricated using the hand-lay-up method. The volume percentage of steel metal rod/pipe was varied from 0 to $10 \%$ and glass fiber from 50 to 60\%, while the percentage of epoxy was kept $40 \%$ stable. The improved wear performance was observed in steel embedded glass/epoxy composites. To identify the influence of parameter, Taguchi, and ANOVA techniques were used, which are the best tools for statistical analysis. MINITAB ${ }^{\text {TM }}$ version 19 software was used for the analysis of experimental data with considering "smaller is better" as excellent quality. The dry sliding wear performance was optimized to achieving minimal SWR and average CoF. Steel volume 10\%, sliding distance 1000 $m$, and applied load $80 \mathrm{~N}$ were observed as optimum factors to achieving minimal SWR and average CoF. From the analysis of experimental data, it is observed that SWR and average CoF were raised with the rise in the sliding distance and load, whereas it decreased as increased steel volume \%. A considerable reduction in the collective SWR of $50.47 \%$ and CoF of $31.48 \%$ is achieved by reinforcing steel vol. $10 \%$ in E-glass fiber / epoxy composite. At last, the worn surfaces of the hybrid composites are observed through Scanning Electron Microscope (SEM).

(C) 2020 Published by Faculty of Engineering 


\section{INTRODUCTION}

In the past 30 years, the emphasis has been placed on the development of polymeric hybrid laminates. Wear is one of the most common experiences mechanical problems, leading to the substitute of assemblies and components in the design, after that corrosion and fatigue. Many tribological parts like driving wheels, gears, cams, impellers, brakes, nuts and bolts, bushes, bearings, and seals are used in machines. Polymer composites are most widely used for structural applications in the automotive $[1,2]$, aerospace [3], and many more.

The tribological performance of polymer composites is an important research area, which consists of cams, gears, artificially duplicated joints, bearing cages, etc. Stainless steel and Glass fiber strengthen the composites, which play a vital role in enhancing the mechanical properties [4]. Hybrid Composites fabricated of different materials are dissimilar in chemical and physical properties. Reinforcements and matrix play an important role in composites, which have been used to enhance mechanical properties such as wear resistance, hardness, and tensile strength [5].

Reinforcements such as titanium diboride [6], silicon carbide [7], fly ash [8], titanium carbide [9], stainless steel [10], aluminum oxide [11] and boron carbide [12] were improved the wear resistance, tensile strength, and hardness of hybrid composites. Though, the use of reinforcement decreases the ductility of the composite. From these reinforcements, stainless steel along with glass fiber has been selected for this work due to its high elastic modulus, excellent resistance to wear, low coefficient of thermal expansion, and superior strength [13].

Hybrid composites have been fabricated by different methods such as vacuum bagging/autoclave, hand lay-up, liquid resin moulding, compression moulding, filament winding, and pultrusion. Amongst all fabrication methods, hand lay-up is extensively accepted as a viable, economical, and most simple method for manufacturing hybrid composites [5]. Sandeep Agrawal et al. [14] studied the tribological performance of laminates under inert gas environment, oil lubrication, and dry sliding. Experimental studies prove that the coefficient of friction has the highest value under the inert gas condition and after that by dry sliding and wet sliding conditions. Chelladurai et al. [15] studied the tribological performance and morphology of the LM13 aluminum alloy with steel wire with copper-coated reinforcement composites. The authors were reported that the improvement in the mechanical properties of LM13 aluminum alloy with copper-coated steel reinforcement composites. During the wear performance, it is observed that wear rate, mass loss, and CoF are reduced with an increase in the number of copper-coated steel wire reinforced in the composite.

Tribological tests are conducted on wear testing machine in the direction of the fiber in a specific way towards the cylindrical pin for different sliding conditions [16]. Wear rate and $\mathrm{CoF}$ at various applied load finds slid in opposition to a perfectly dry plane of steel and upgrade the friction. Wear rate and $\mathrm{CoF}$ are reduced by about 30-75 \% and 33-62\% correspondingly. This depends upon the typical speed and normal load. Österle et al. [17] studied the tribological behavior of polymer matrix composites in addition to filler particles such as nano-sized silica particles and micro-sized carbon fibers. Li et al. [18] studied the tribological performance of hybrid Kevlar fabric/PTFE composite with submicron size WS2 and nano - Si3N4. The results show that C3N4 fillers can efficiently decrease the wear of polymer composites and at the same time it does not reduce the CoF. The hybrid composite WS2 and C3N4 filler particles can effectively reduce the wear rate and $\mathrm{CoF}$ of the composite. Hybrid WS2 and C3N4 filler particle composites can significantly decrease the wear rate and CoF.

Molazemhosseini et al. [19] investigated the wear behavior of polyether-ketone hybrid composites with surface-modified nano-SiO2 particles with the compositions $1,1.5$, and 2 wt $\%$ and short carbon fibers (20 vol. \%). The result shows that the wear rate and CoF are impacted vigorously due to the filler particle content for example wear rate is increased and $\mathrm{CoF}$ is reduced as increasing in the filler particle content. Chelladurai et al. [20] studied the optimization and microstructure behavior of the dry sliding wear factors by response surface method of AA336 aluminum alloy with steel wire copper coated reinforced composites. Loss 
in weight of the composites laminates was predicted by the regression model and verified its competence with the help of confirmation test, analysis of variance, and significance tests. From the microstructure study, it shows that the bonding between reinforcement and matrix was improved by using steel wire in the composites.

Basavarajappa et al. [21] investigated the tribological performance under the dry condition of graphite particles fillers in glassepoxy composites. The result shows that the reduction in volume loss was observed due to the addition of filler particles. This happens due to the uniform film and thin coherence that was active on the disc. Hashmi et al. [22] studied the tribological performance of cotton-based FRP composites with graphite under dry sliding conditions. From the study, it was found that the significant enhancement of the CoF in cottonbased FRP composites and decreased significantly in the use of graphite filler particles. The significant reduction in the temperature of the mating surface was observed due to the use of graphite filler particles. Bahadur and Polineni [23] studied the effect of $\mathrm{CuO}$ and PTFE filled in the GFRP composites. The authors stated that the wear rate was reduced of the GFRP composite for the composition $\mathrm{CuO} 25$ vol. \%, PTFE 10 vol. \%, and glass fiber11.3 vol. \%. Friction and wear were decreased in the composite with the addition of PTFE 10 vol. \% of filler particles. The results show that the wear rate reduced by around $60-75 \%$ on the addition of filler particles. B. Suresha et al. [24] investigated three-body abrasive wear performance of glass fiber-epoxy and carbon fiber-epoxy. The result shows that the significant reduction in SWR and wear volume loss was observed at different applied load and abrading distance. It was also observed that the decrease in the SWR with an increase in abrading distance and increase with the load. Various optimization techniques used for mathematical modeling and statistical analysis are used to wear investigations like Taguchi, RSM, GRA, ANOVA, and so on [25-37]. In the present study, the wear performance of steel embedded glass fiber/epoxy hybrid (SGFPC) composites with variation between 0 to $10 \%$ of steel was investigated to identify the effect of steel embedded in polymer laminates on tribological behavior. Wear behavior such as SWR and average CoF were evaluated in detail. ANOVA analyses were carried out to identify the influencing factor. The dry sliding wear mechanism of Hybrid polymer composites was evaluated by examining the scanning electron microscopy (SEM) images. This method was implemented to explain the wear mechanism.

\section{MATERIAL AND METHOD}

\subsection{Materials}

Epoxy resin (LY-556) was used as a matrix material and hardener (HY951) was used at room temperature. E-glass fiber was chosen as a reinforcement material. Spring steel (EN48D) was also chosen as a reinforcement material. The selection of the matrix was done based on their good adhesion properties and good resistance to alkalis. A thin layer of a mixture prepared of hardener and epoxy resin with a ratio of $1: 10$ as per the recommendation of the supplier was used for the preparation of hybrid composite specimens. The details of compositions of E glass fiber and spring steel are shown in Tables 1 and 2.

Table 1. Chemical Composition of Glass fiber (E-glass).

\begin{tabular}{|c|c|c|c|c|c|c|c|c|c|}
\hline (\%) & 令 & 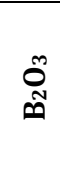 & $\frac{\overbrace{N}^{N}}{\gtrless}$ & $\sum^{\infty 00}$ & ర్ల & 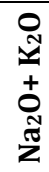 & 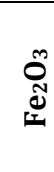 & $\stackrel{N}{\stackrel{N}{O}}$ & N \\
\hline E-glass & 54 & 10 & 13 & 5 & 17 & 2 & 0.5 & 1 & 0.5 \\
\hline
\end{tabular}

Size of glass fiber $=20 \mu \mathrm{m}$

Table 2. Chemical Composition of steel.

\begin{tabular}{|c|c|c|c|c|c|c|c|c|c|}
\hline (\%) & C & $\mathbf{S i}$ & Mn & $\mathbf{P}$ & $\mathbf{S}$ & $\mathbf{N i}$ & $\mathrm{Cr}$ & Mo & $\mathbf{F e}$ \\
\hline Steel & 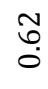 & $\stackrel{\widetilde{N}}{0}$ & $\stackrel{m}{\stackrel{0}{0}}$ & $\begin{array}{l}\vec{H} \\
\stackrel{+}{0} \\
0\end{array}$ & $\begin{array}{l}\text { O̊ } \\
\text { O̊ }\end{array}$ & 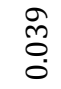 & $\stackrel{\check{N}}{0}$ & $\begin{array}{l}0 \\
\stackrel{0}{0} \\
0\end{array}$ & 嘼 \\
\hline
\end{tabular}

Size of steel rod - D = $2.25 \mathrm{~mm}$

where, $\mathrm{D}=$ diameter of steel rod.

Size of steel pipe $-\mathrm{D}=7.7 \mathrm{~mm}, \mathrm{~d}=7 \mathrm{~mm}$, where, $\mathrm{D}=$ Outer diameter of steel pipe, $\mathrm{d}=$ Inner diameter of steel pipe. The length of the rod and pipe is $30 \mathrm{~mm}$.

\subsection{Fabrication}

A hand layup method was used to fabricate the steel embedded glass fiber-epoxy composite (SGFPC) laminates. The specimens were 
prepared in such a way that it has a size of 30 $\mathrm{mm}$ length and $10 \mathrm{~mm}$ diameter as shown in Fig. 1 and as per the ASTM G99 standard. Epoxy is a solid adhesive substance, which is used to treat various substances, the surface of which is covered jointly. For safety, a combined combination of glass fiber and resin is used with a hardener with steel.

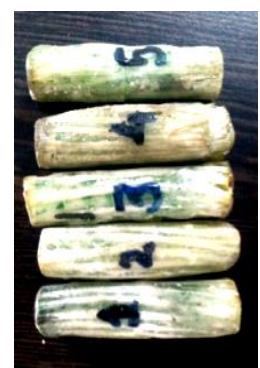

W1

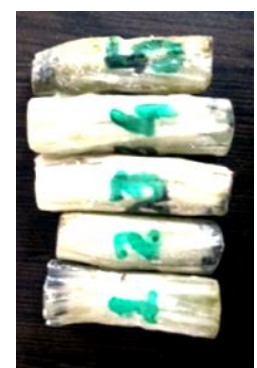

W2

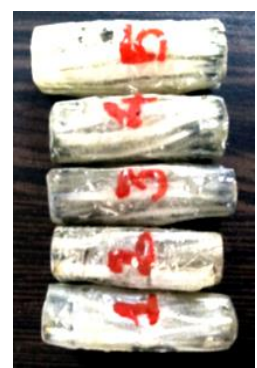

W3
Fig. 1. Illustration of raw pin prepared for wear testing.

The hardener selected for this work is Ardur (HY951), which is used as part of the performance of composite components. It is cured with a mixture of resin composites at room temperature, whereas it has a life-long and extremely low viscosity property. It has an acid versus chemical compound resistance which is raised to $80{ }^{\circ} \mathrm{C}$ [26]. The chemical environment has a resistant property due to the composite atmospheric conditions of this resin material.

Glass fiber and steel were selected as reinforcing medium for this work. Glass fiber was treated with sized, paired operating agents to reduce the influence of friction on the fiber, which reduces the mechanical property for the individual material of the fiber. As part of the experiment, glass fiber was used in low alkali base glass. Glass fibers have the most amazing power with extreme rigidity, enormous resistance to heat, insensitivity to moisture, and good chemical compounds resistance [38].

In the present work, SGFPC (a combination of glass fiber, steel, and epoxy resin) composites were prepared to investigate the tribological behavior. When preparing the sample, the LY556 mixture of epoxy resin was solidified manually by using a hardener HY951 at room temperature of in the ratio of 10:1. In this process, a steel rod and a pipe of the required diameter were used. The knurling process was carried out on the surface of the steel rod and pipe to enhance the bonding between glass fiber/epoxy mixture and steel. The dried glass fibers mixed with epoxy resin were rolled over a steel rod and pipe to form an SGFPC pin. Different composite samples were fabricated with the variation of steel contribution from $0 \%$ to $10 \%$. The overall volume of the pin was calculated for the plain composites (Total volume $=\pi / 4^{*} \mathrm{~d}^{2 *} \mathrm{~L}$ ).

Table 3. Details of Specimen compositions.

\begin{tabular}{|c|c|c|c|c|}
\hline \multirow{2}{*}{$\begin{array}{c}\text { Specimen } \\
\text { Code }\end{array}$} & \multirow{2}{*}{$\begin{array}{c}\text { Matrix } \\
\text { (Vol. \%) }\end{array}$} & \multicolumn{2}{|c|}{$\begin{array}{c}\text { Reinforcement } \\
\text { (vol. \%) }\end{array}$} & \multirow{2}{*}{$\begin{array}{c}\text { Density } \\
\text { g/cc }\end{array}$} \\
\cline { 3 - 4 } & & E-glass fiber & Steel & \\
\hline W1 & 40 & 60 & 0 & 2.05 \\
\hline W2 & 40 & 55 & 5 & 2.28 \\
\hline W3 & 40 & 50 & 10 & 2.43 \\
\hline
\end{tabular}

\subsection{Experimental set-up}

The wear characteristics were performed on the machine names as wear tester pin or ball on the disc manufactured by DUCOM ${ }^{\mathrm{TM}}$, Bangalore, India. All experimentations were carried in the laboratory at relative humidity $=42 \%$ and temperature $=24{ }^{\circ} \mathrm{C}$. Figures $2 \mathrm{a}$ and $2 \mathrm{~b}$ show the experimental set up in which the specimen was fixed in the stationary arm.

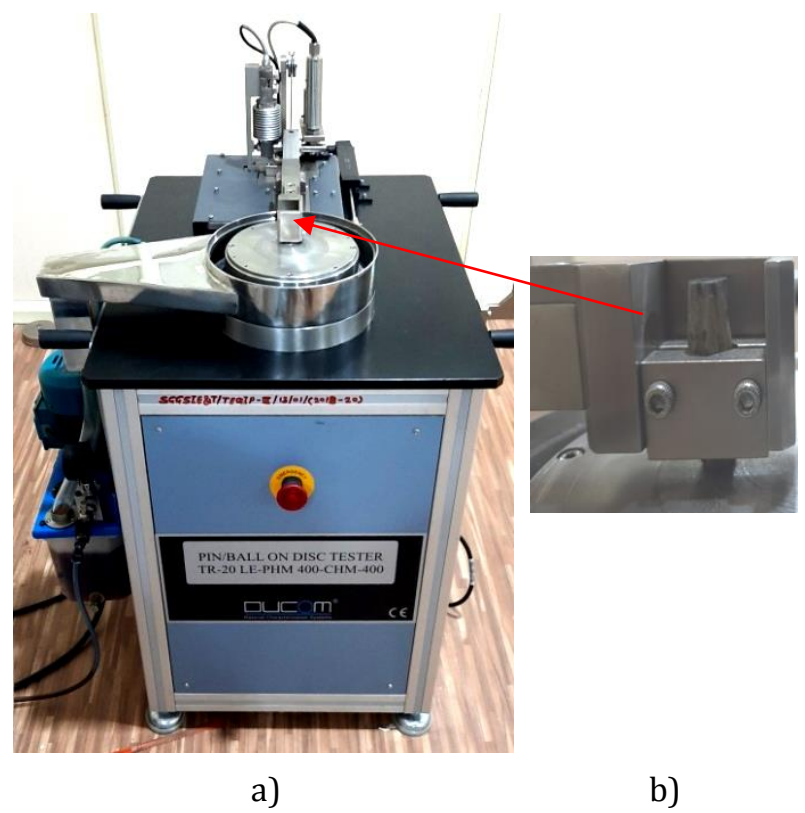

Fig. 2. a) Experimental setup for wear testing, b) Pin clamped in the holder.

The surface of the pin is slid on the flat surface of the rotating EN31 disc of hardness 58-62 HRc. The rotating disc used in wear test was made of EN31 having dimensions of $8 \mathrm{~mm}$ thickness and $165 \mathrm{~mm}$ diameter. The 
experiments were carried out at a track diameter of $80 \mathrm{~mm}$ at a particular load, speed, and sliding distance for the specified time duration. The specimen is fixed on the stationary arm over the rotating disc surface with the two degrees of freedom: the horizontal for the measurement of friction and the vertical for the applied load. The standard metallurgical procedure was used for the prepared specimen surface.

Before starting the experiment, the surface of the disk and the sample were uncontaminated with the help of acetone. In every experiment weight before test and weight after the test was noted accurately with the help of a digital electronic weighing machine of least count 0.001 g. Once the specimen is fixed in the stationary holder assembly, the normal load was applied to the specimen with the help of a pivoted lever with a pan assembly and string. The selected load was applied by placing the required weight on the pan assembly. The experiments were carried out by applying a load, test duration, and speed, and results were analyzed with Winducom 2010 Software. The sliding distance is determined by the following equation:

$$
\text { Sliding distance }(S d)=\frac{\pi D N T}{60000}
$$

whereas $N$ is the speed of disc in revolution per minute, $D$ is track diameter in $\mathrm{mm}, T$ is the time duration in a minute, sliding distance is in $\mathrm{m}$. After the completion of the experiment, the specimen was removed from the wear testing machine and weighted in the same weighing machine. The difference between initial and final weight was noted as weight loss. The SWR is determined by the following equation:

$$
\text { Sp. wear rate }(\mathrm{SWR})=\frac{\Delta m}{\rho L S d}
$$

whereas $\rho$ is the density of composite specimen in $\mathrm{gm} / \mathrm{mm}^{3}, \Delta m$ is weight loss in $\mathrm{g}, \quad L$ is normal load in $\mathrm{N}, S d$ is sliding distance in $\mathrm{m}$, $S p$. wear rate (SWR) is in $10^{-4} \mathrm{~mm}^{3} / \mathrm{Nm}$

\subsection{Test Parameters}

The experimentation was carried under laboratory conditions and the testing parameters are steel reinforcement volume \% (0 - 10), sliding distance (1000 - $2000 \mathrm{~m}$ ), applied load (80 - $100 \mathrm{~N}$ ), and test duration (20 min.). MINITAB $^{\text {TM }}$ version 19 was used to design of experiments (DOE). Three levels and three factors were used for wear testing. In the present study, an $\mathrm{L}_{27}$ orthogonal array technique is selected and it has 3 columns and 27 rows. The orthogonal array was selected based on the degree of freedom criterion.

A minimum of three tests was conducted at the same conditions. The repeatability of the tribology test was recognized by determining the variation coefficient and it was within the acceptable limit of $10 \%$. Out of all factors which are selected for the testing, one factor is material dependent such that steel volume $\%$ and other remaining two factors like applied load and sliding distance are process dependent. The levels and factors for the experimentation are shown in Table 4.

Table 4. Levels and Factors.

\begin{tabular}{|c|c|c|c|}
\hline Level & $\begin{array}{c}\text { Reinforcement } \\
\text { vol. \% }\end{array}$ & $\begin{array}{c}\text { Applied } \\
\text { Load (N) }\end{array}$ & $\begin{array}{c}\text { Sliding } \\
\text { distance (m) }\end{array}$ \\
\hline 1 & $\begin{array}{c}0 \% \text { (steel) \& } \\
60 \% \text { glass fiber }\end{array}$ & 80 & 1000 \\
\hline 2 & $\begin{array}{c}5 \% \text { (steel) \& } \\
55 \% \text { glass fiber }\end{array}$ & 90 & 1500 \\
\hline 3 & $\begin{array}{c}10 \% \text { (steel) \& } \\
50 \% \text { glass fiber }\end{array}$ & 100 & 2000 \\
\hline
\end{tabular}

Signal to noise $(\mathrm{S} / \mathrm{N})$ ratio is mainly categorized in three types for quality characteristics i.e. nominal is better, larger is better, smaller is better in Taguchi analysis. The lower SWR and average CoF of the SGFPC were accepted. Thus, the $\mathrm{S} / \mathrm{N}$ ratio of the "smaller is better" was used for the analysis. The following equation was used to calculate the $\mathrm{S} / \mathrm{N}$ ratio:

$$
\frac{S}{N}=-10 * \log \left(\frac{\sum Y^{2}}{n}\right)
$$

where, $\mathrm{Y}=$ every observed value, $n$ number of runs in a trial.

\section{RESULT AND DISCUSSION}

The hybrid combination of fiber-reinforced materials and steel is being used for many applications. The study of the wear of these composite laminates is needed to replace the existing material. The addition of steel in the composites enhances their wear properties and strength. To launch the hybrid composite material parts in the industries, the wear 
behaviors were studied. Wear behavior of the steel embedded composites was investigated. Figs. 3 and 4 show the charts produced by the wear testing machine. Figure 3 shows the wear loss concerning time in micron. It also shows that the wear loss was nearly constant after some time. Figure 4 expresses the behavior of CoF over time.

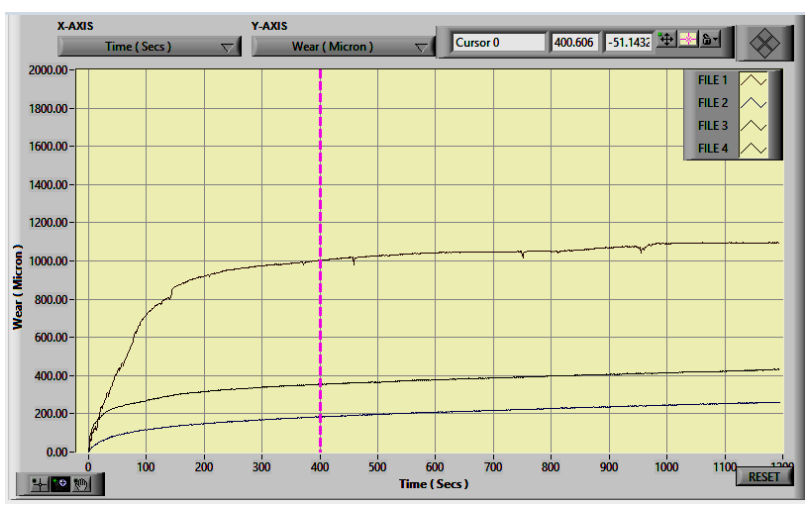

Fig. 3. Graphs generated during testing for wear loss on wear testing machine.

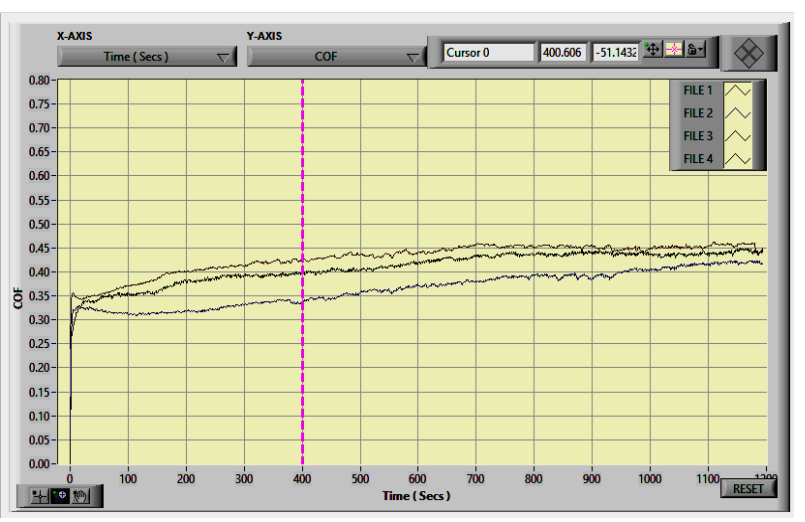

Fig. 4. Graph generated during testing for CoF on wear testing machine.

\subsection{The Effect of sliding distance on the wear properties}

When the steel is embedded in the hybrid composite, the influence of the sliding distance on tribological behavior is shown in Figs. 5 and 6. The SWR and average CoF of SGFPC are affected concerning sliding distance. Figures 5 and 6 indicates the graphs of SWR and average $\mathrm{CoF}$ at a load of $80 \mathrm{~N}$ with varying sliding distance. This type of behavior is true in both plain and steel embedded composites. Figs. 5 and 6 show the general effects of sliding distance on both the plain (steel vol. 0\%) and steel embedded composites. The results from Fig. 5 show that the addition of steel reduces the SWR.
Whereas the SWR and average CoF increases as sliding distance increased. At a high sliding distance, the temperature increases between the mating surface due to the poor conductivity of the hybrid composite laminates. The molten layer was induced at the mating surface due to high temperature which affects the bonding of matrix - fiber on the subsurface. It also encourages the crack propagation and wears on the mating surface. The results also show that the SWR and average CoF increases rapidly over the sliding distance. The same behavior of sliding distance over the SWR of composites was reported by S. Basavarajappa [7].

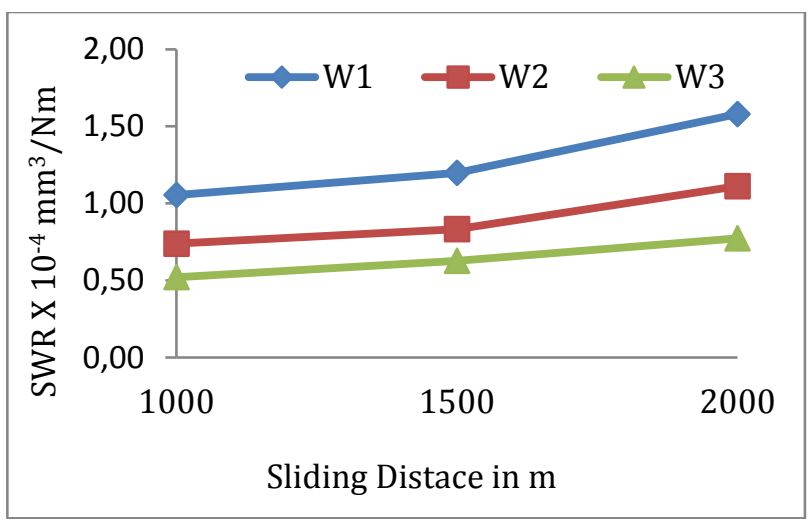

Fig. 5. Sliding distance Vs SWR at $80 \mathrm{~N}$ load.

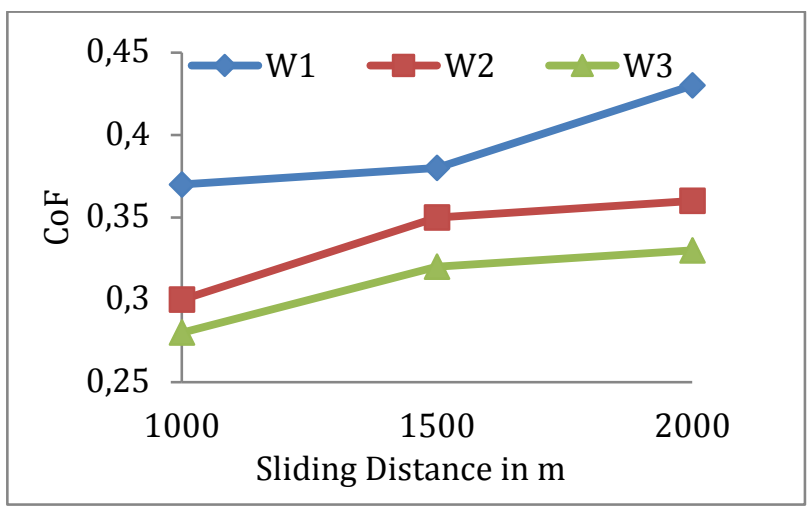

Fig. 6. Sliding distance Vs CoF at $80 \mathrm{~N}$ load.

From Fig. 6, it is observed that at the starting of the rubbing action, the average CoF is considerably low due to the layer of the pin on the disc. Slowly the rubbing starts to wear the pin material due to the contact takes place between the disc and pin material. The value of average $\mathrm{CoF}$ is low for the low sliding distance and then it starts to increase gradually for higher sliding distance. Figure 6 shows that the reduction in average CoF with the addition of steel. This may happen due to the reinforcement of tough steel in soft E-glass fiber/epoxy matrix 
which reduces the tangential force as constant sliding of the composite pin. The same behavior of sliding distance over the average CoF of composites was reported by Samson Jerold Samuel Chelladurai [15]. For W2 and W3 specimens, the average $\mathrm{CoF}$ was increasing when sliding distance increase from 1000 to $1500 \mathrm{~m}$ but suddenly rate of increment was reduced as sliding distance increased from 1500 to $2000 \mathrm{~m}$.

\subsection{Effect of load on wear properties.}

Wear experiments on hybrid composites that are performed under normal load with 80, 90, and $100 \mathrm{~N}$ at varying sliding distance from 1000 , 1500 , and $2000 \mathrm{~m}$. At varying sliding distances and normal loads, variations of average CoF and SWR concerning time are investigated. Figures 7-8 shows the behavior of normal loads on the SWR and average CoF on both the plain and steel embedded composites.

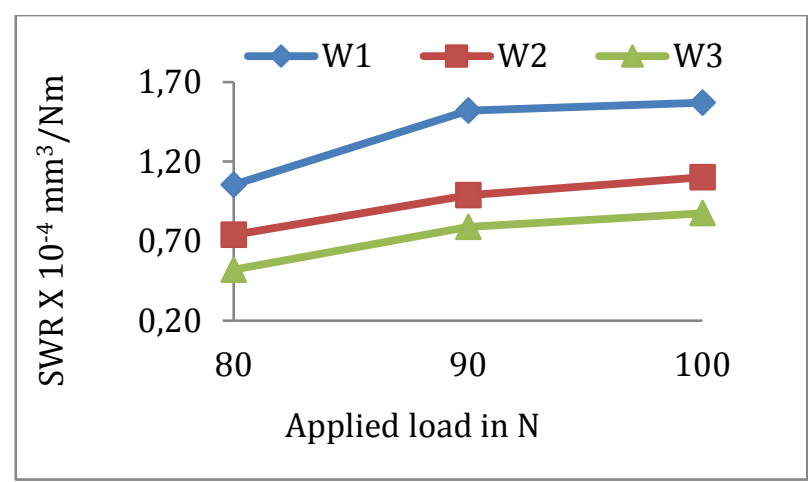

Fig. 7. Load Vs SWR at $1000 \mathrm{~m}$ sliding distance.

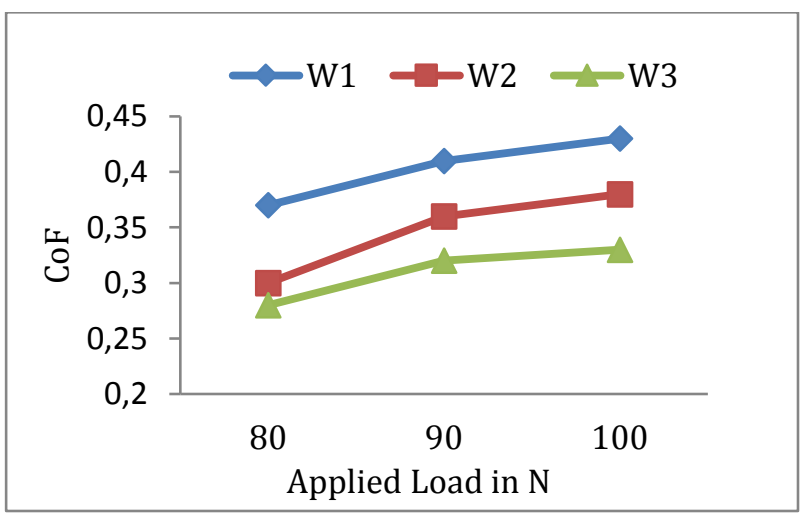

Fig. 8. Load Vs CoF at $1000 \mathrm{~m}$ Sliding distance.

Figure 7 shows that the reduction in SWR due to the reinforcement of steel. Figure 8 shows that the SWR raises with the rise in normal load. The same behavior of load over the SWR of composites was reported by Samson Jerold
Samuel Chelladurai [13]. It also shows that the increase in the contribution of steel reduces the SWR. SWR rise with the rise in normal load from 80 to $90 \mathrm{~N}$ drastically but the further increment in SWR is low as normal load increase from 90 to $100 \mathrm{~N}$. Figure 8 shows the influence of normal loads on average CoF. The result shows that the average $\mathrm{CoF}$ rises as a rise in normal load, whereas the addition of steel reduces the CoF. The same behavior of load over the average CoF of composites was reported by Rajesh S. Godse [40].

\subsection{Effect of Time on wear properties.}

Experiments are carried out on hybrid composite at different normal loads from 80 to $100 \mathrm{~N}$ and sliding distance from 1000 to $2000 \mathrm{~m}$ at different time intervals $(5,10,15$, and 20 minutes). Figure 9 shows the variation of SWR at different time intervals. SWR is rising as time increase from 0 to 1200 seconds.

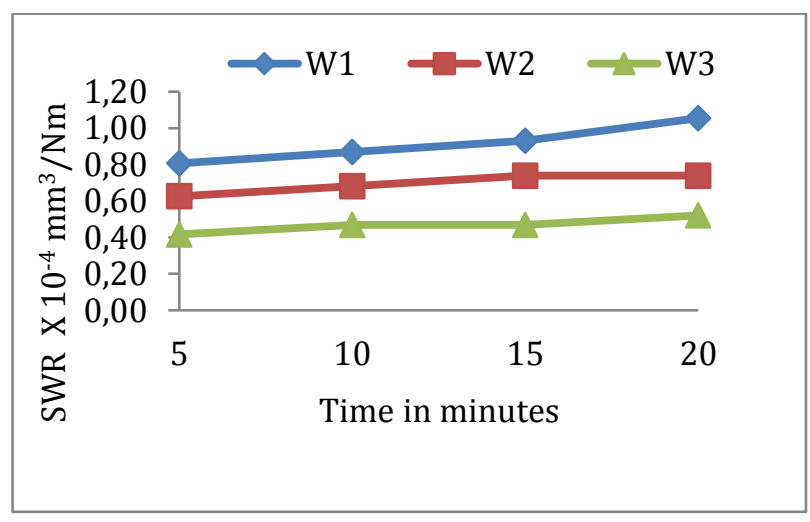

Fig. 9. Time Vs SWR at $80 \mathrm{~N}$ load and $1000 \mathrm{~m}$ Sliding distance.

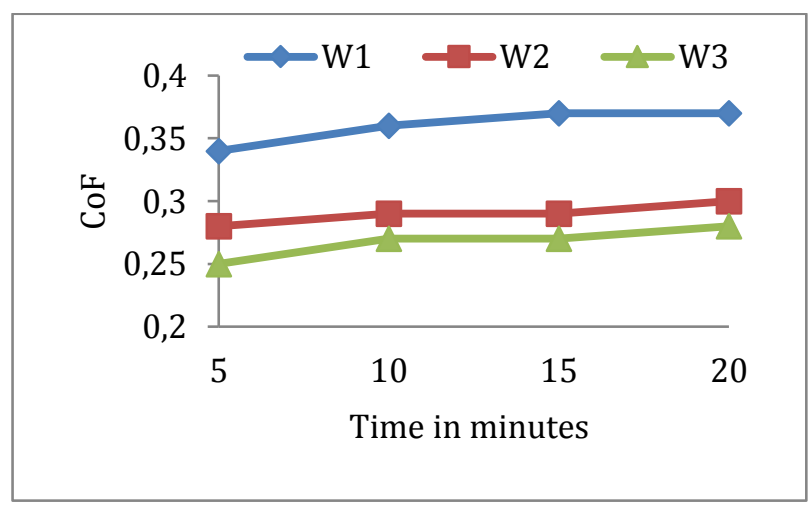

Fig. 10. Time Vs CoF at $80 \mathrm{~N}$ load and $1000 \mathrm{~m}$ Sliding distance.

The results show that the sudden increase in SWR at the start of experiments, whereas the increment in SWR was moderate after some 
time intervals. All the steel embedded hybrid composites result in enhancing the wear performance as compared to plain composites. The SWR of the W3 is minimal as compared to the W2 and W1 specimens, indicating an improvement in the wear performance of the plain composite due to reinforcement of steel of 10 vol. $\%$ and 5 vol. \%. The same behavior of time over wear of composites was reported by A. A. Megahed [41]. Figure 10 shows the influence of time over average CoF. The result shows that the average CoF increases as an increase in time, whereas the addition of steel reduces the average $\mathrm{CoF}$.

\subsection{Taguchi and ANOVA method for analysis of wear performance}

The optimization of the responses and the testing data were analyzed with the help of Taguchi DOE technique in which the $\mathrm{S} / \mathrm{N}$ ratios are considered "smaller is better". Purpose of this setting to achieve the lowest SWR and CoF occurs on steel embedded E-glass fiber/epoxy composites (SGFPC). The maximum value of S/N ratios for every factor gives the minimum SWR and CoF. Hence the maximum value of the $\mathrm{S} / \mathrm{N}$ ratio for every parameter is to consider the best possible setting to get the minimum average $\mathrm{CoF}$ and SWR of SGFPC. The data collected through the Taguchi experiments for the SWR and average CoF of SGFPC at the various grouping of factors are shown in Table 5.

Table 5. Experimental design based on $\mathrm{L}_{27} \mathrm{OA}$ and results of SWR and average CoF.

\begin{tabular}{|c|c|c|c|c|c|}
\hline $\begin{array}{c}\text { Expt. } \\
\text { No. }\end{array}$ & $\begin{array}{c}\text { Steel } \\
\text { Vol. } \\
\mathbf{\%}\end{array}$ & $\begin{array}{c}\text { Load } \\
\text { (N) }\end{array}$ & $\begin{array}{c}\text { Sliding } \\
\text { Distance } \\
\text { (m) }\end{array}$ & $\begin{array}{c}\text { SWR x } \\
\mathbf{1 0}^{-4} \\
\mathbf{m m}^{\mathbf{3}} \text { /Nm }\end{array}$ & $\begin{array}{c}\text { Average } \\
\text { Coefficient } \\
\text { of Friction } \\
\text { (CoF) }\end{array}$ \\
\hline 1 & 0 & 80 & 1000 & 1.05 & 0.37 \\
\hline 2 & 0 & 80 & 1500 & 1.20 & 0.38 \\
\hline 3 & 0 & 80 & 2000 & 1.58 & 0.43 \\
\hline 4 & 0 & 90 & 1000 & 1.52 & 0.41 \\
\hline 5 & 0 & 90 & 1500 & 1.89 & 0.41 \\
\hline 6 & 0 & 90 & 2000 & 2.34 & 0.47 \\
\hline 7 & 0 & 100 & 1000 & 1.57 & 0.43 \\
\hline 8 & 0 & 100 & 1500 & 1.91 & 0.46 \\
\hline 9 & 0 & 100 & 2000 & 2.63 & 0.54 \\
\hline 10 & 5 & 80 & 1000 & 0.74 & 0.30 \\
\hline 11 & 5 & 80 & 1500 & 0.83 & 0.35 \\
\hline 12 & 5 & 80 & 2000 & 1.11 & 0.36 \\
\hline 13 & 5 & 90 & 1000 & 0.99 & 0.36 \\
\hline 14 & 5 & 90 & 1500 & 1.43 & 0.40 \\
\hline
\end{tabular}

\begin{tabular}{|c|c|c|c|c|c|}
\hline 15 & 5 & 90 & 2000 & 1.73 & 0.38 \\
\hline 16 & 5 & 100 & 1000 & 1.10 & 0.38 \\
\hline 17 & 5 & 100 & 1500 & 1.41 & 0.41 \\
\hline 18 & 5 & 100 & 2000 & 2.00 & 0.41 \\
\hline 19 & 10 & 80 & 1000 & 0.52 & 0.28 \\
\hline 20 & 10 & 80 & 1500 & 0.63 & 0.32 \\
\hline 21 & 10 & 80 & 2000 & 0.77 & 0.33 \\
\hline 22 & 10 & 90 & 1000 & 0.79 & 0.32 \\
\hline 23 & 10 & 90 & 1500 & 0.99 & 0.33 \\
\hline 24 & 10 & 90 & 2000 & 1.17 & 0.34 \\
\hline 25 & 10 & 100 & 1000 & 0.88 & 0.33 \\
\hline 26 & 10 & 100 & 1500 & 1.04 & 0.33 \\
\hline 27 & 10 & 100 & 2000 & 1.27 & 0.37 \\
\hline
\end{tabular}

\subsubsection{Taguchi analysis of wear performance.}

The main effect plot for the $\mathrm{S} / \mathrm{N}$ ratios for $\mathrm{SWR}$ is shown in Fig. 11a and the main effect plot for the means for SWR is shown in Fig. 11b. Figure 11a shows the optimal experiment situation for lowest SWR of SGFPC is steel volume at $10 \%$, applied normal load at $80 \mathrm{~N}$, and sliding distance of $1000 \mathrm{~m}$.

Table 6. Response Table for Signal to Noise Ratios Smaller is better.

\begin{tabular}{|c|c|c|c|}
\hline Level & $\begin{array}{c}\text { Steel } \\
\text { Vol. \% }\end{array}$ & Load (N) & $\begin{array}{c}\text { Sliding } \\
\text { Distance (m) }\end{array}$ \\
\hline 1 & -4.4999 & 1.0240 & 0.3013 \\
\hline 2 & -1.5911 & -2.6148 & -1.4890 \\
\hline 3 & 1.2705 & -3.2297 & -3.6327 \\
\hline Delta & 5.7704 & 4.2537 & 3.9340 \\
\hline Rank & 1 & 2 & 3 \\
\hline
\end{tabular}

Table 7. Response Table for Means.

\begin{tabular}{|c|c|c|c|}
\hline Level & $\begin{array}{c}\text { Steel } \\
\text { Vol. \% }\end{array}$ & Load (N) & $\begin{array}{c}\text { Sliding } \\
\text { Distance (m) }\end{array}$ \\
\hline 1 & 1.7435 & 0.9379 & 1.0182 \\
\hline 2 & 1.2603 & 1.4271 & 1.2583 \\
\hline 3 & 0.8957 & 1.5344 & 1.6229 \\
\hline Delta & 0.8478 & 0.5965 & 0.6047 \\
\hline Rank & 1 & 3 & 2 \\
\hline
\end{tabular}

Table 6 shows the $\mathrm{S} / \mathrm{N}$ ratios response table of SWR and Table 7 shows the means response table for SWR. According to Table 6, steel volume $\%$ is the most influencing factor on wear performance of SGFPC with a delta value of 5.7704 (max-min value), then the load (4.2537), and finally sliding distance (3.9340). Figure $13 \mathrm{~b}$ depicts that the SWR reduces as an increase in steel reinforcement. This occurs because of the addition of steel in the composites, which increased the hardness of SGFPC. 
The main effect plot for the $\mathrm{S} / \mathrm{N}$ ratios for average CoF is shown in Fig. 18a and the main effect plot for the means for average $\mathrm{CoF}$ is shown in Fig. 18b. Figure 18a shows the optimal experiment condition for minimum average $\mathrm{CoF}$ of SGFPC is steel volume $\%$ at $10 \%$, applied normal load at $80 \mathrm{~N}$, and sliding distance of 1000 $\mathrm{m}$. Table 8 shows the $\mathrm{S} / \mathrm{N}$ ratios response table of average CoF and Table 9 shows the means response table for average CoF. According to Table 8 , steel volume $\%$ is the most influencing factor on wear performance of SGFPC with a delta value of 2.392 (max-min value), then the applied normal load (1.354), and finally sliding distance (1.126). Figure 18b shows that the CoF increases as an increase in steel reinforcement.

Table 8. Response Table for Signal to Noise Ratios Smaller is better.

\begin{tabular}{|c|c|c|c|}
\hline Level & $\begin{array}{c}\text { Steel } \\
\text { Vol. \% }\end{array}$ & $\begin{array}{c}\text { Load } \\
\text { (N) }\end{array}$ & $\begin{array}{c}\text { Sliding } \\
\text { Distance (m) }\end{array}$ \\
\hline 1 & 7.316 & 9.267 & 9.114 \\
\hline 2 & 8.620 & 8.465 & 8.541 \\
\hline 3 & 9.708 & 7.913 & 7.989 \\
\hline Delta & 2.392 & 1.354 & 1.126 \\
\hline Rank & 1 & 2 & 3 \\
\hline
\end{tabular}

Table 9. Response Table for Means.

\begin{tabular}{|c|c|c|c|}
\hline Level & $\begin{array}{c}\text { Steel } \\
\text { Vol. \% }\end{array}$ & $\begin{array}{c}\text { Load } \\
\text { (N) }\end{array}$ & $\begin{array}{c}\text { Sliding } \\
\text { Distance (m) }\end{array}$ \\
\hline 1 & 0.4333 & 0.3467 & 0.3533 \\
\hline 2 & 0.3722 & 0.3800 & 0.3767 \\
\hline 3 & 0.3278 & 0.4067 & 0.4033 \\
\hline Delta & 0.1056 & 0.0600 & 0.0500 \\
\hline Rank & 1 & 2 & 3 \\
\hline
\end{tabular}

The residual plot for average SWR and CoF is shown in Figs. 12 and 19 respectively; generated using MINITAB ${ }^{\text {TM }} 19$ software, explains detail about testing data reliability. The tendency of testing data is nearer to the middle value as shown in the normal probability plot for residuals. The residuals are intense much at the lower error; however, it representing that the responses are reliable from the data analysis.

The interaction plots for average SWR and CoF are shown in Figs. 13 and 20 respectively concerning three factors. Figures 14 and 21 shows the Pareto chart of the standardized effects for SWR and average CoF. Figures 15-17 shows the surface plot of the SWR given two factors. The surface plots are 3D projections shown with the colored area. These areas show the SWR concerning affecting variables. Figures 22-24 shows the surface plot of the average CoF given two factors. The surface plots are 3D projections shown with the colored area. These areas show the average CoF concerning affecting variables.

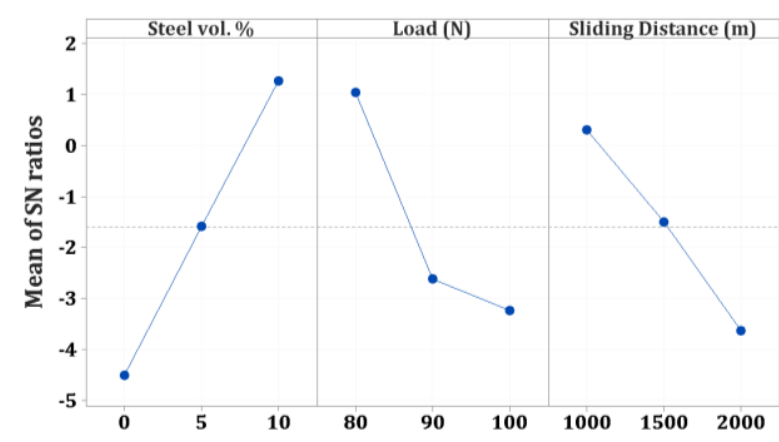

Signal-to-noise: Smaller is better

(a)

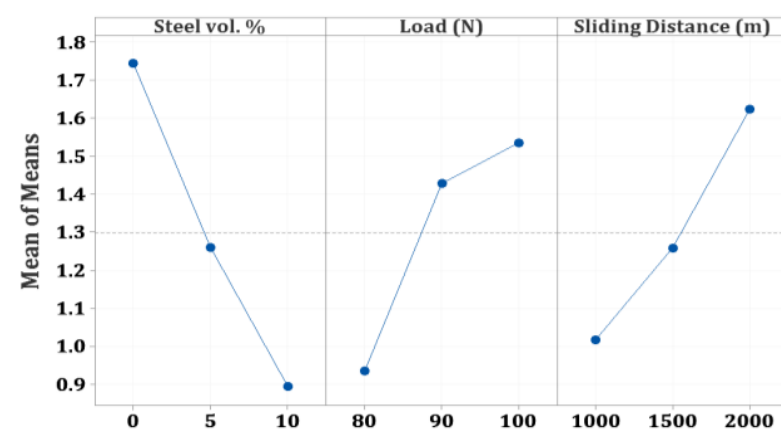

(b)

Fig. 11. a) Main effect plot for $S / N$ ratio SWR, b) Main effect plot for means SWR.
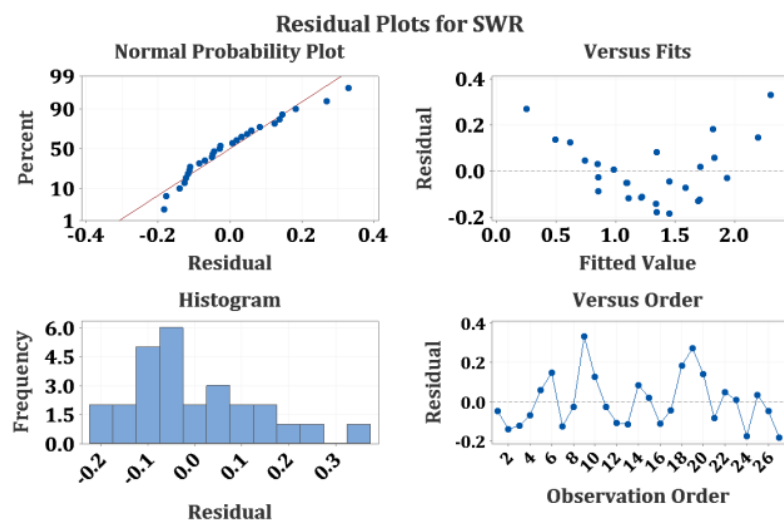

Fig. 12. Residual plots for SWR from Taguchi.

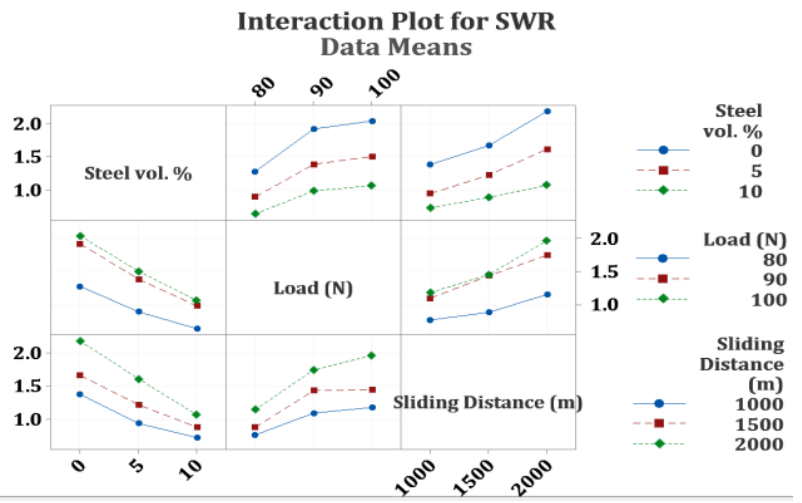

Fig. 13. Interaction plots for SWR from Taguchi. 


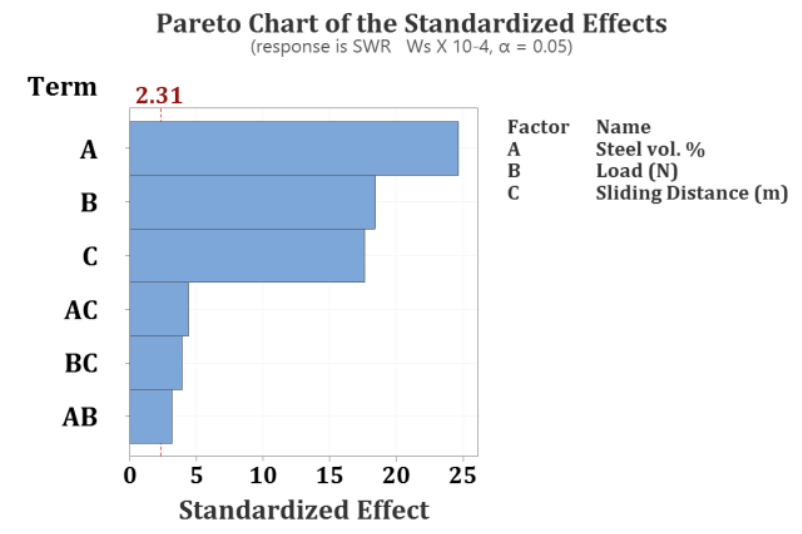

Fig. 14. Pareto chart of the standardized effects for SWR.

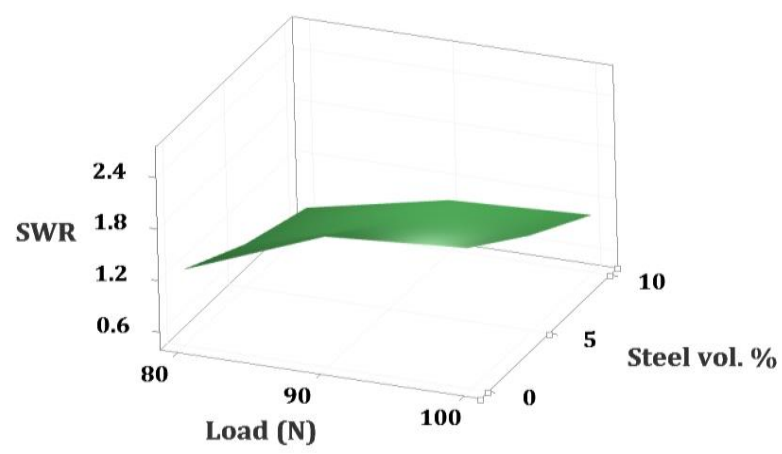

Fig. 15. Surface plot of SWR Vs Steel vol. \% and Load (N) from Taguchi.

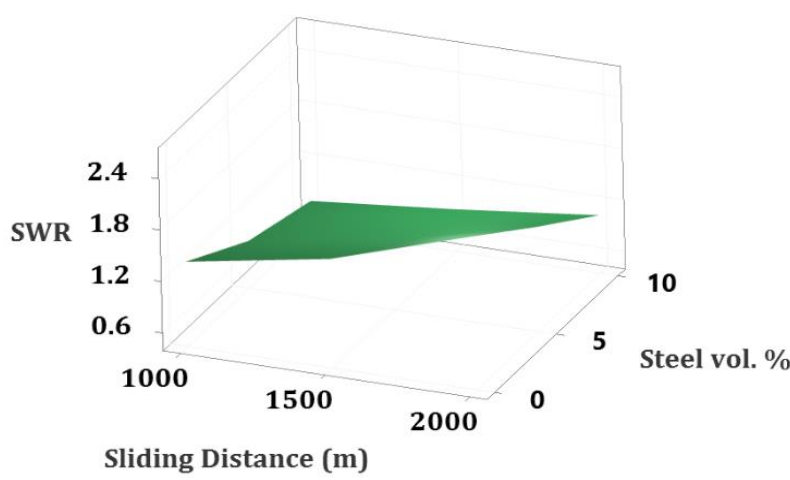

Fig. 16. Surface plot for SWR Vs Steel vol. \% and sliding distance $(\mathrm{m})$ from Taguchi.

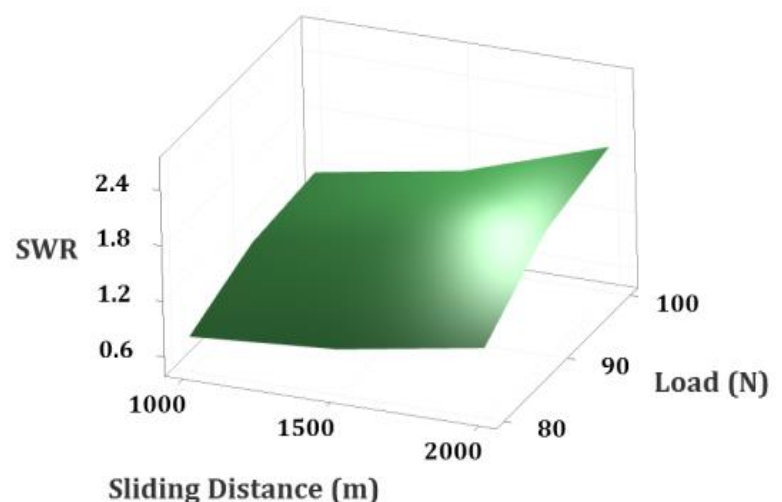

Fig. 17. Surface plots for SWR Vs Load (N) and sliding distance $(\mathrm{m})$ from Taguchi.

\subsubsection{ANOVA analysis of wear performance.}

Analysis of variance (ANOVA) is performed to investigate the contribution of the percentage of factors to the results i.e. SWR and average CoF. ANOVA is carried out using MINITAB ${ }^{\text {TM }} 19$ software for the level of confidence $95 \%$ (i.e. the level of significance of $5 \%$ ).

Table 10. Analysis of Variance for SWR.

\begin{tabular}{|c|c|c|c|c|c|c|c|}
\hline Source & DF & Seq SS & $\begin{array}{l}\text { Contri- } \\
\text { bution }\end{array}$ & Adj SS & Adj MS & $\begin{array}{c}\text { F- } \\
\text { Value }\end{array}$ & $\begin{array}{c}\text { P- } \\
\text { Value }\end{array}$ \\
\hline Model & 18 & 7.16234 & $99.57 \%$ & 7.16234 & 0.39791 & 102.83 & 0.000 \\
\hline Linear & 6 & 6.74415 & $93.76 \%$ & 6.74415 & 1.12402 & 290.47 & 0.000 \\
\hline Steel Vol. \% & 2 & 3.25527 & $45.25 \%$ & 3.25527 & 1.62763 & 420.62 & 0.000 \\
\hline Load $(\mathrm{N})$ & 2 & 1.82005 & $25.30 \%$ & 1.82005 & 0.91002 & 235.17 & 0.000 \\
\hline \begin{tabular}{|c} 
Sliding \\
Distance (m)
\end{tabular} & 2 & 1.66883 & $23.20 \%$ & 1.66883 & 0.83441 & 215.63 & 0.000 \\
\hline $\begin{array}{c}\text { 2-Way } \\
\text { Interactions }\end{array}$ & 12 & 0.41819 & $5.81 \%$ & 0.41819 & 0.03485 & 9.01 & 0.002 \\
\hline $\begin{array}{l}\text { Steel Vol. } \\
\% * \text { Load }\end{array}$ & 4 & 0.10084 & $1.40 \%$ & 0.10084 & 0.02521 & 6.51 & 0.012 \\
\hline $\begin{array}{c}\text { Steel Vol. } \\
\% * \text { Sliding } \\
\text { Distance }\end{array}$ & 4 & 0.17528 & $2.44 \%$ & 0.17528 & 0.04382 & 11.32 & 0.002 \\
\hline $\begin{array}{c}\text { Load* } \\
\text { Sliding } \\
\text { Distance }\end{array}$ & 4 & 0.14207 & $1.98 \%$ & 0.14207 & 0.03552 & 9.18 & 0.004 \\
\hline Error & 8 & 0.03096 & $0.43 \%$ & 0.03096 & 0.00387 & & \\
\hline Total & 26 & 7.19330 & $100 \%$ & & & & \\
\hline
\end{tabular}

The results of the ANOVA for SWR are shown in Table 10. From the results of the ANOVA investigation, it was observed that every factor i.e. steel volume \%, sliding distance, and load affects the SWR of SGFPC. Column 8 in Table 10 shows the effect (p) of every factor on the entire deviation of the result that is on the SWR. Table 10 shows that all factors (steel vol. \%, load, and sliding distance) have no (zero) effect on the deviation in the result of the SWR, while these factors are considered separately. Therefore every factor is considered significant, while the interaction of factors has some effect on the deviation in the result of the SWR. The interaction effect of Steel Volume \%* Load $(\mathrm{N})$, Steel Volume \%* Sliding Distance (m), and Load (N) * Sliding Distance (m) is also significant at the certain extent at the level of confidence 95 $\%$. From column 4 in Table 10 shows the percentage contribution in the dry sliding wear of SGFPC. Steel volume \% is the most significant variable having the maximum contribution percentage $(45.25 \%)$ in the dry sliding wear of SGFPC after that the load (25.30\%) and finally sliding distance $(23.20 \%)$. Therefore the steel volume $\%$ is a significant control factor to be 
considered while the incidence of SWR after that applied load and sliding distance. It is observed from Table 11 that the $\mathrm{R}^{2}$ value is $99.57 \%$ which is higher than the confidence level $95 \%$ and therefore it shows that the results are satisfactory.

Table 11. Model Summary for SWR.

\begin{tabular}{|c|c|c|c|c|c|c|}
\hline S & $\begin{array}{c}\text { R-sq } \\
\%\end{array}$ & $\begin{array}{c}\text { R-sq } \\
\text { (adj) } \\
\%\end{array}$ & PRESS & $\begin{array}{c}\text { R-sq } \\
\text { (pred) } \\
\%\end{array}$ & AICc & BIC \\
\hline 0.0622065 & 99.57 & 98.60 & 0.352622 & 95.10 & 73.81 & -40.28 \\
\hline
\end{tabular}

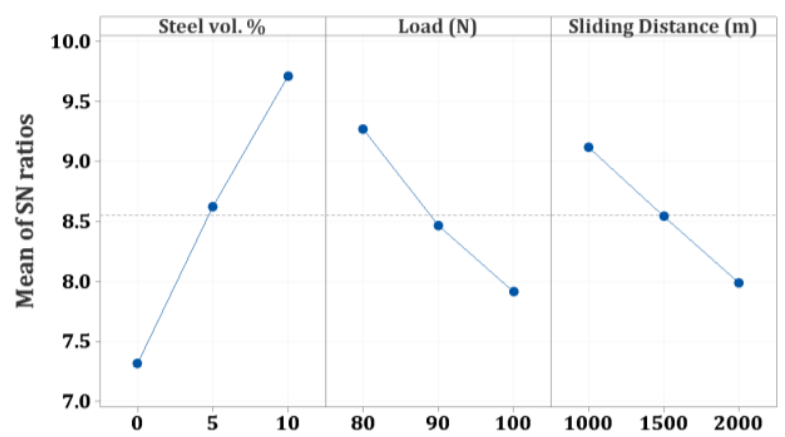

Signal-to-noise: Smaller is better

(a)

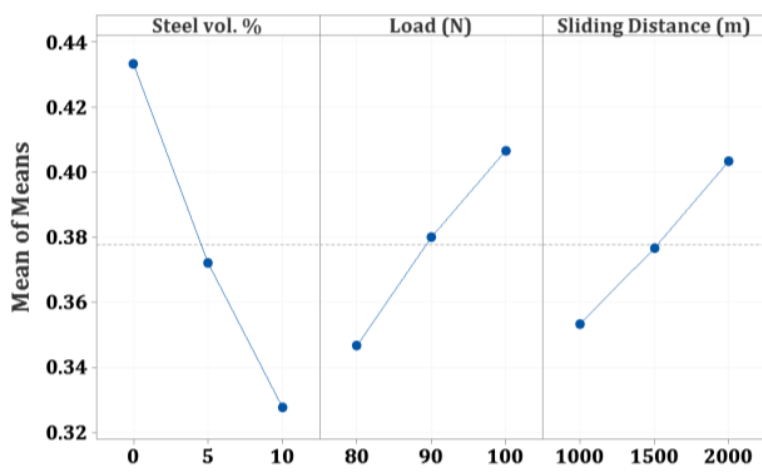

(b)

Fig. 18. a) Main effect's plot for $S / N$ ratio - CoF, b) Main effects plot for means-CoF.
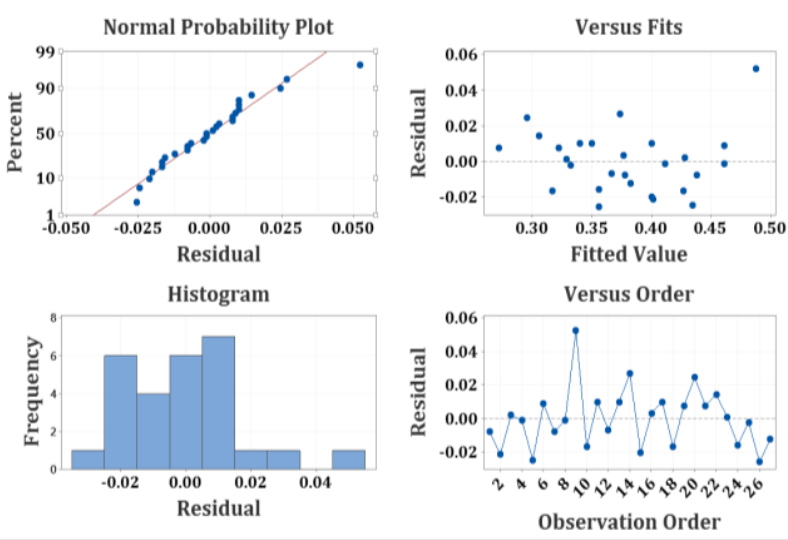

Fig. 19. Residual plots for $\mathrm{CoF}$ from Taguchi.

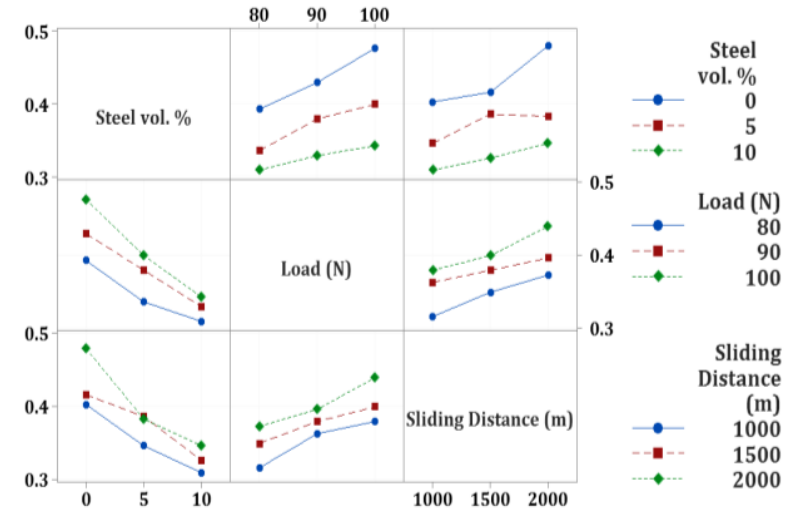

Fig. 20. Interaction plots for $\mathrm{CoF}$ from Taguchi.

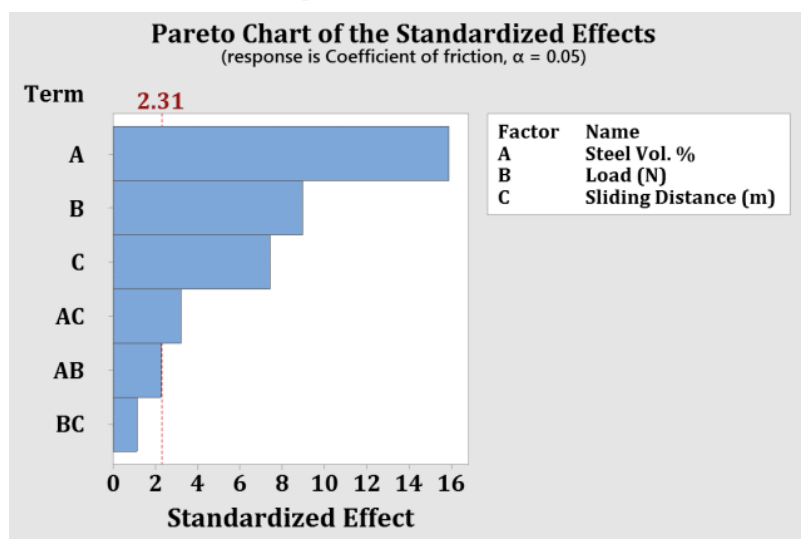

Fig. 21. Pareto chart of the standardized effects for SWR.

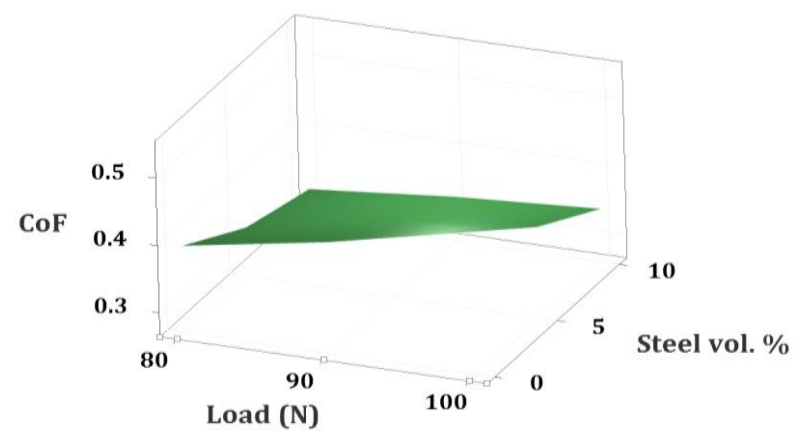

Fig. 22. Surface plots of CoF Vs Steel vol. \% and Load (N) from Taguchi.

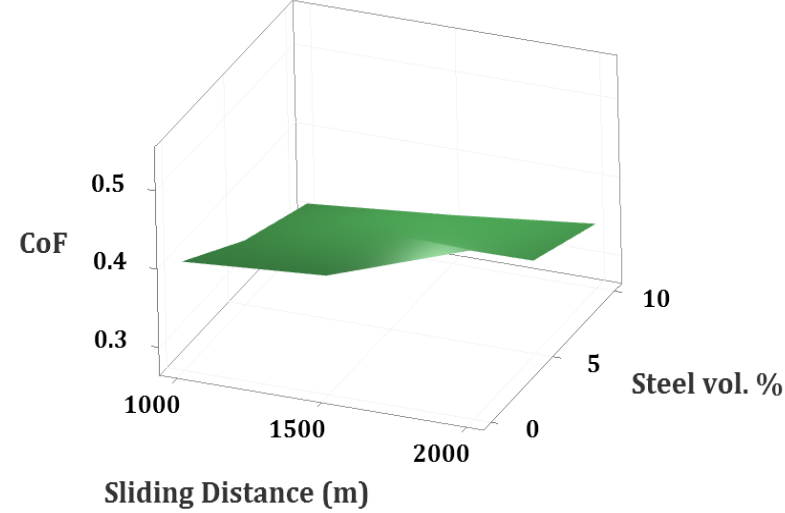

Fig. 23. Surface plots for CoF Vs Steel vol. \% and sliding distance $(\mathrm{m})$ from Taguchi. 


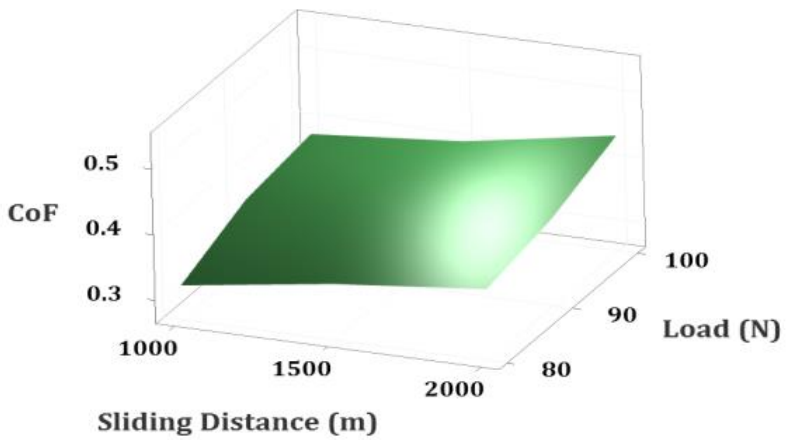

Fig. 24. Surface plots for CoF Vs Load (N) and sliding distance $(\mathrm{m})$ from Taguchi.

Table 12. Analysis of Variance for CoF.

\begin{tabular}{|c|c|c|c|c|c|c|c|}
\hline Source & DF & Seq SS & $\begin{array}{c}\text { Contri- } \\
\text { bution }\end{array}$ & Adj SS & Adj MS & $\begin{array}{c}\text { F- } \\
\text { Value }\end{array}$ & $\begin{array}{c}\text { P- } \\
\text { Value }\end{array}$ \\
\hline Model & 18 & 0.084911 & $98.66 \%$ & 0.084911 & 0.004717 & 32.66 & 0.000 \\
\hline Linear & 6 & 0.078089 & $90.73 \%$ & 0.078089 & 0.013015 & 90.10 & 0.000 \\
\hline $\begin{array}{c}\text { Steel } \\
\text { Vol. \% }\end{array}$ & 2 & 0.050556 & $58.74 \%$ & 0.050556 & 0.025278 & 175.0 & 0.000 \\
\hline Load (N) & 2 & 0.016267 & $18.90 \%$ & 0.016267 & 0.008133 & 56.31 & 0.000 \\
\hline $\begin{array}{c}\text { Sliding } \\
\text { Distance } \\
\text { (m) }\end{array}$ & 2 & 0.011267 & $13.09 \%$ & 0.011267 & 0.005633 & 39.00 & 0.000 \\
\hline $\begin{array}{c}\text { 2-Way } \\
\text { Interaction }\end{array}$ & 12 & 0.006822 & $7.93 \%$ & 0.006822 & 0.000569 & 3.94 & 0.030 \\
\hline $\begin{array}{c}\text { Steel Vol. } \\
\% * \text { Load }\end{array}$ & 4 & 0.002178 & $2.53 \%$ & 0.002178 & 0.000544 & 3.77 & 0.052 \\
\hline $\begin{array}{c}\text { Steel Vol. } \\
\% * \text { Sliding } \\
\text { Distance }\end{array}$ & 4 & 0.003778 & $4.39 \%$ & 0.003778 & 0.000944 & 6.54 & 0.012 \\
\hline $\begin{array}{c}\text { Load } \\
\text { Sliding } \\
\text { Distance }\end{array}$ & 4 & 0.000867 & $1.01 \%$ & 0.000867 & 0.000217 & 1.50 & 0.289 \\
\hline Error & 8 & 0.001156 & $1.34 \%$ & 0.001156 & 0.000144 & & \\
\hline Total & 26 & 0.086067 & $100 \%$ & & & & \\
\hline
\end{tabular}

Table 13. Model Summary for average CoF.

\begin{tabular}{|c|c|c|c|c|c|c|}
\hline S & $\begin{array}{c}\text { R-sq } \\
\mathbf{\%}\end{array}$ & $\begin{array}{c}\text { R-sq } \\
\mathbf{( a d j )} \\
\mathbf{\%}\end{array}$ & PRESS & $\begin{array}{c}\text { R-sq } \\
\text { (pred) } \\
\mathbf{\%}\end{array}$ & AICc & BIC \\
\hline 0.0120185 & 98.66 & 95.64 & 0.0131625 & 84.71 & -14.97 & -129.05 \\
\hline
\end{tabular}

The results of ANOVA for average CoF are shown in Table 12. From Table 12 of ANOVA investigation, it observed that all factors i.e. steel volume \%, load, and sliding distance affect the average CoF of SGFPC. Column 8 in Table 12 shows the effect ( $p$ ) of every factor on the entire deviation of the result that is on CoF. Table 12 shows that all factors (steel volume \%, load, and sliding distance) have no (zero) effect on the deviation in the result of average CoF, while these factors are considered separately. Therefore every factor is considered significant, while the interaction of factors has some effect on the deviation in the evaluation of CoF. The interaction effect of Steel Volume \%* Load $(\mathrm{N})$, Load $(\mathrm{N}) *$ Sliding Distance $(\mathrm{m})$, and Steel Volume $\%$ * Sliding Distance (m) is also significant at the certain extent at the level of confidence $95 \%$. From column 4 in Table 12 shows the percentage contribution in the dry sliding wear of SGFPC. Steel vol. \% is the mainly significant variable having the maximum contribution percentage $(58.74 \%)$ in the dry sliding wear of SGFPC after that the load $(18.90 \%)$ and finally sliding distance (13.09\%). Therefore the steel volume \% is a significant control factor to be considered while the incidence of $\mathrm{CoF}$ after that sliding distance and load. It is observed from Table 13 that the $\mathrm{R}^{2}$ value is $98.66 \%$ which is higher than the confidence level $95 \%$ and therefore it shows that the results are satisfactory.

\subsubsection{Regression Equation model}

SWR $=-1.873-0.08478$ Steel volume $\%$ +0.02989 Load $(\mathrm{N})+0.000604$ Sliding Distance (m) (4)

CoF $=0.0856-0.010556$ Steel volume $\%$ +0.003000 Load (N)+0.000050 Sliding Distance (m) (5)

\subsubsection{Confirmation test}

The confirmation test is carried out to validate the optimal conditions achieved for the SWR and CoF. From equations 4 and 5, the predicted value of SWR and CoF was calculated. Table 13 shows the result of the confirmation test.

Table 13. Results of confirmation test.

\begin{tabular}{|c|c|c|c|c|c|c|c|}
\hline $\begin{array}{c}\text { Expt. } \\
\text { No. }\end{array}$ & $\begin{array}{c}\text { Steel } \\
\text { Vol. } \\
\text { \% }\end{array}$ & $\begin{array}{c}\text { Load } \\
\text { (N) }\end{array}$ & $\begin{array}{c}\text { Sliding } \\
\text { Distance } \\
\text { (m) }\end{array}$ & $\begin{array}{c}\text { Expt. } \\
\text { SWR }\end{array}$ & $\begin{array}{c}\text { Expt. } \\
\text { CoF }\end{array}$ & $\begin{array}{c}\text { Pred. } \\
\text { SWR }\end{array}$ & $\begin{array}{c}\text { Pred. } \\
\text { CoF }\end{array}$ \\
\hline 1 & 0 & 84 & 1200 & 1.37 & 0.24 & 1.36 & 0.23 \\
\hline 2 & 5 & 91 & 1600 & 1.41 & 0.20 & 1.39 & 0.21 \\
\hline 3 & 10 & 98 & 1800 & 1.33 & 0.18 & 1.30 & 0.19 \\
\hline
\end{tabular}

\subsubsection{Worn surface}

The SEM images of the worn surface for different steel vol. \%, sliding distance, and applied load of SGFPC are as shown in Figs. 25-27. Figure 25 shows the fibers disturbed glass fibers along the sliding direction. This maybe happens because of poor bonding between the glass fibers and matrix. The SEM image of a $5 \%$ volume fraction of steel embedded composite is shown in Fig. 26. 


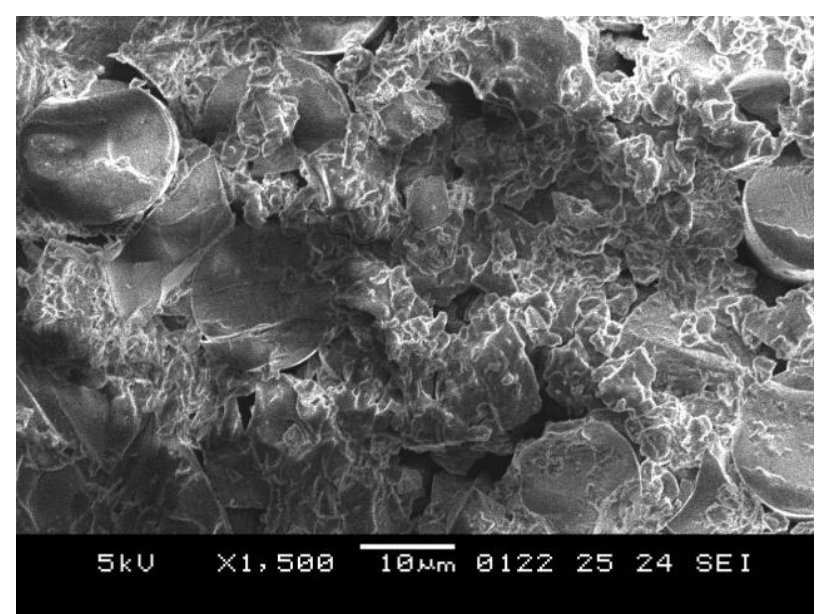

Fig. 25. SEM image of worn surface of $0 \%$ steel embedded composite

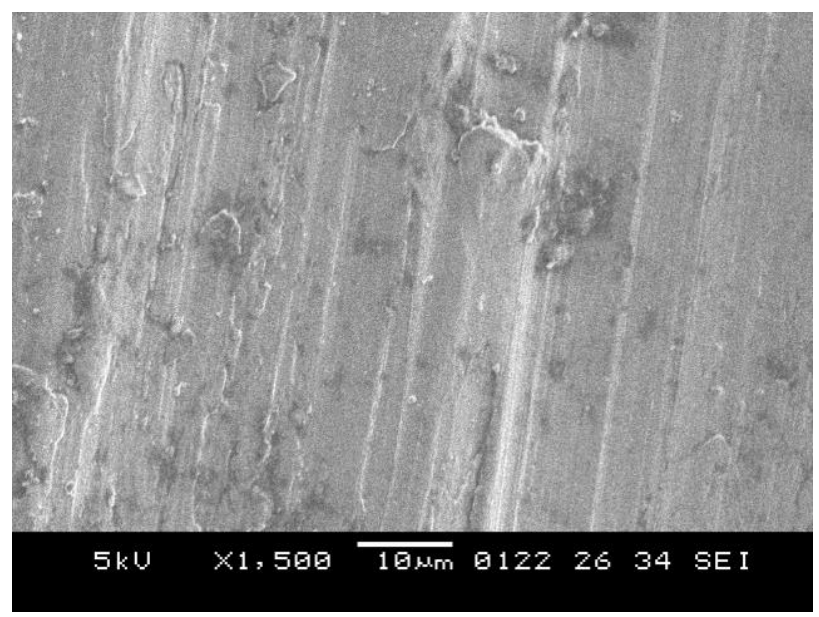

Fig. 26. SEM image of worn surface of $5 \%$ steel embedded composite.

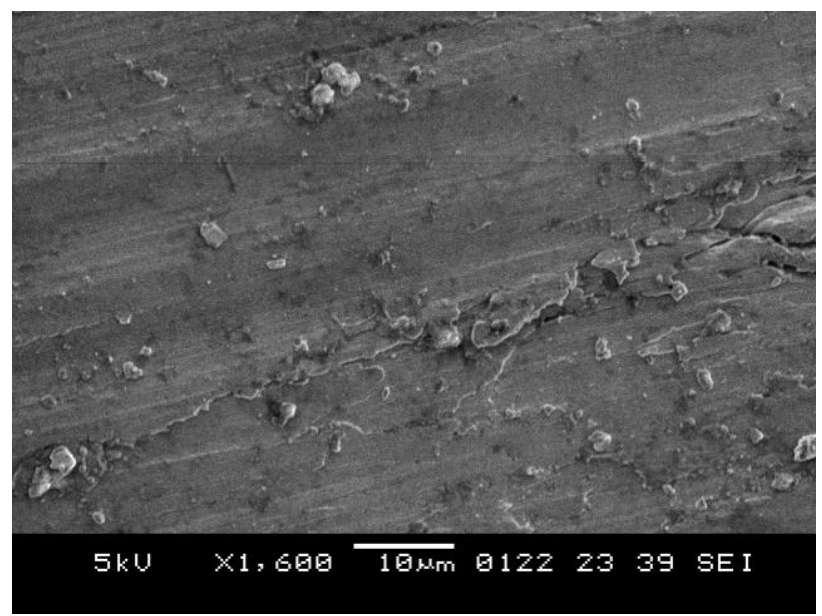

Fig. 27. SEM image of worn surface of $10 \%$ steel embedded composite.

The SEM image of a $10 \%$ volume fraction of steel embedded composite is shown in Fig. 27. From the figures, it observed that the fiber pull out was lowered as compared to $0 \%$ vol. steel embedded composite. It also observed that the existence of small grooves along the sliding direction, whereas thin grooves were found in few areas. This can be happened by the presence of steel which acts as a load-carrying component that prevents the contact between disc and pin. The presence of steel in composite would carry the load and avoid the shifting of the load towards the matrix and glass fiber, resulting in reduced SWR as compared to plain composite. This is favorable for wear applications. From the SEM micrograph, it is also observed that the worn surface is mainly composed of longitudinal grooves and partial irregular pits along the sliding direction. The presence of grooves indicates the micro-cutting and micro-ploughing effect of the counterface while pits or prows are indicative of adhesive wear failure of epoxy.

\section{CONCLUSIONS}

The tribological performance of SGFPC was investigated over the pin on disc wear machine under different factors. Based on the experimental results and analysis, the following conclusions were drawn.

1. The SWR and average CoF of SGFPC decrease as the increase in steel volume \%., whereas it increases as increasing applied load, and sliding distance. A considerable reduction in the collective SWR of $50.47 \%$ is achieved by reinforcing steel vol. $10 \%$ in E-glass fiber / epoxy composite. Similarly, the reduction in average CoF $31.48 \%$ is achieved by reinforcing steel vol.10 \% in E-glass / epoxy composites.

2. The SWR and CoF increase as an increase in time for the wear test. The results show that the sudden increase in SWR and average CoF at the start of experiments, whereas the increment in SWR and average CoF was moderate after some time intervals.

3. The results of the $\mathrm{S} / \mathrm{N}$ ratio show that the steel volume $\%$ is the most significant parameter on the SWR and average CoF followed by applied load and finally sliding distance.

4. The results of ANOVA show that the steel volume \% causes $45.25 \%$ of the SWR (it is the most important contributing factor), followed by applied load causes $25.30 \%$ and 
at last sliding distance causing $23.20 \%$ for the investigated SGFPC.

5. The results of ANOVA show that the steel volume \% causes $58.74 \%$ of the average CoF (it is the most important contributing factor), followed by applied load causes $18.90 \%$, and at last sliding, distance causing $13.09 \%$ for the investigated SGFPC.

6. The $\mathrm{R}^{2}$ values for the SWR and average CoF are $99.57 \%$ and $98.66 \%$ respectively, which is higher than the confidence level $95 \%$.

7. A steel volume $\%$ of $10 \%$, applied load $80 \mathrm{~N}$, and sliding distance $1000 \mathrm{~m}$ were observed as optimum conditions to achieve minimum SWR and average CoF.

8. 3D surface plots are generated: it facilitates in predicting SWR and average CoF at any selected conditions.

9. Scanning Electron Microscope (SEM) shows that the pits on the surface of the image were covered with voids and other defects. Also, it shows that the porosity of the specimen decreases with increasing fractional volume of steel in the composite.

\section{REFERENCES}

[1] G.R. Chavhan, L.N. Wankhade, Experimental analysis of E-glass fiber/epoxy compositematerial leaf spring used in automotive, MaterialsToday: Proceedings, vol. 26, pp. 373377, 2020, doi: 10.1016/j.matpr.2019.12.058

[2] S.W. Burande, G.R. Chavhan, L.P. Dhole, Analysis of leaf springs in light automotive vehicles by experimental and finite element, International Journal of Advanced Engineering Research Studies, vol. 4, no. 1, pp. 15-16, 2014.

[3] M. Fiorina, A. Seman, B. Castanie, K.M. Ali, C. Schwob, L. Mezeix, Spring-in prediction for carbon/epoxy aerospace composite structure, Composte Structure, vol. 168, pp. 739-745, 2017, doi: 10.1016/j.compstruct.2017.02.074

[4] R. Velmurugan, R. Ranga Raj, C. Dinesh, S.Balaji, Experimental test of stainless steel wire mesh and aluminium alloy with glass fiber reinforcement hybrid composite, International Journal of Engineering Research and Applications, vol. 5, iss. 5, pp. 80-88, 2015.

[5] G.R. Chavhan, L.N. Wankhade, Improvement of the mechanical properties of hybrid composites prepared by fibers, fiber-metals, and nano-filler particles $\quad-A$ review, MaterialsToday: Proceedings, vol. 27, pp. 72-82. 2020, doi: 10.1016/j.matpr.2019.08.240

[6] X. Li, X. Zhang, Y. Guo, V.P.W. Shim, J. Yang, G. Boay, Influence of fiber type on the impact response of titanium-based fiber-metal laminates, International Journal of Impact Engineering, Vol. 114, pp. 32-42, 2018, doi: 10.1016/j.ijimpeng.2017.12.011

[7] S. Basavarajappa, S. Ellangovan, Dry sliding wear characteristics of glass-epoxy composite filled with silicon carbide and graphite particles, Wear, vol. 296, iss. 1-2, pp. 491-496, 2012, doi: 10.1016/j.wear.2012.08.001

[8] A.H. Pujari, S.C. Kulkarni, Mechanical and tribological properties of aluminium 6061 alloy with flyash and zirconia flour hmmcs, International Research Journal of Engineering and Technology, vol. 4, iss. 5, pp. 3074-3078, 2017.

[9] S. Sulaiman, S. Sulaiman, J.N. Najmiyah, Y.N. Imrah, Studies on tensile properties of titanium carbide (tic) particulates composites, Advanced Materials Research, vol. 903, pp. 151-156, 2014, doi: 10.4028/www.scientific.net/AMR.903.151

[10] R. Gecu, A. Karaaslan, Relationship between nanoindentation and wear properties of stainless steel-reinforced aluminium matrix composite, Tribology Letter, vol. 65, p. 164, 2017, doi: 10.1007/s11249-017-0950-5

[11] K. Devendra, T. Rangaswamy, Strength characterization of e-glass fiber reinforced epoxy composites with filler materials, Journal of Minerals and Materials Characterization and Engineering, vol. 1, iss. 6, pp. 353-357, 2013, doi: 10.4236/jmmce.2013.16054

[12] S.K.J. Basha, K.L.N. Murthy, Y.S. Kumar, Design and optimization of a heavy vehicle leaf spring by the material e-glass epoxy and aluminum alloy reinforced with boron carbide, Advanced Research Journals of Science and Technology (ARJST), vol. 4, iss. 1, pp. 334-340, 2017.

[13] S.J.S. Chelladurai, R. Arthanari, A.N. Thangaraj, H. Sekar, Dry sliding wear characterization of squeeze cast LM13/FeCu composite using response surface methodology, China Foundry, vol. 14, pp. 525-533, 2017, doi: 10.1007/s41230-017-7101-3

[14] S. Agrawal, K.K. Singh, P.K. Sarkar, Comparative investigation on the wear and friction behaviors of carbon fiber reinforced polymer composites under dry sliding, oil lubrication and inert gas environment, MaterialsToday: Proceedings, vol. 5, iss. 1, pp. 1250-1256, 2018, doi: 10.1016/j.matpr.2017.11.208 
[15] S.J.S. Chelladurai, R. Arthanari, R. Selvarajan, R. Kanagaraj, P. Angappan, Investigation on microstructure and tensile behavior of stir cast LM13 aluminum alloy reinforced with coppercoated short steel fibers using response surface methodology, Transactions of the Indian Institute of Metals, vol. 71, pp. 2221-2230, 2018, doi: $10.1007 / \mathrm{s} 12666-018-1353-5$

[16] N.S. El-Tayeb, M. Gadelrab, Friction and wear properties of e-glass fiber reinforced epoxy composites under different sliding contact conditions, Wear, vol. 192, iss. 1-2, pp. 112-117, 1996, doi: 10.1016/0043-1648(95)06770-1

[17] W. Österle, A.I. Dmitriev, B. Wetzel, G. Zhang, I. Häusler, B.C. Jim, The role of carbon fibers and silica nanoparticles on friction and wear reduction of an advanced polymer matrix composite, Materials \& Design, vol. 93, pp. 474484, 2016, doi: 10.1016/j.matdes.2015.12.175

[18] H. Li, Z.W. Yin, D. Jiang, Y. Huo, Y.Q. Cui, Tribological behavior of hybrid PTFE/Kevlar fabric composites with nano-Si3N4 and submicron size WS2 fillers, Tribology International, vol. 80, pp. 172-178, 2014, doi: 10.1016/j.triboint.2014.07.006

[19] A. Molazemhosseini, H. Tourani, A. Khavandi, B.E. Yekta, Tribological performance of peek based hybrid composites reinforced with short carbon fibers and nano-silica, Wear, vol. 303, iss. 1-2, pp. 397-404, 2013, doi: 10.1016/j.wear.2013.03.019

[20] S.J.S. Chelladurai, R. Arthanari, R. Selvarajan, T.P. Ravichandran, S.K. Ravi, S.R.C. Petchimuthu, Optimisation of dry sliding wear parameters of squeeze cast aa336 aluminium alloy: copper-coated steel wire-reinforced composites by response surface methodology, International Journal of Metalcasting, vol. 13, pp. 354-366, 2019, doi: 10.1007/s40962-0180258-8

[21] S. Basavarajappa, S. Ellangovan, K.V. Arun, Studies on dry sliding wear behavior of graphite filled glass-epoxy composites, Materials \& Design, vol. 30, iss. 7, pp. 2670-2675, 2009, doi: 10.1016/j.matdes.2008.10.013

[22] S.A.R. Hashmi, U.K. Dwivedi, N. Chand, Graphite modified cotton fiber reinforced polyester composites under sliding wear conditions, Wear, vol. 262 , iss. $11-12$, pp. $1426-1432$, 2007, doi: 10.1016/j.wear.2007.01.014

[23] S. Bahadur, V.K. Polineni, Tribological studies of glass fabric-reinforced polyamide composites filled with $\mathrm{CuO}$ and PTFE, Wear, vol. 200, iss. 1-2, pp. 95-104, 1996, doi: 10.1016/S00431648(96)07327-9
[24] B. Suresha, G. Chandramohan, Siddaramaiah, P. Samapthkumaran, S. Seetharamu, Three-body abrasive wear behavior of carbon and glass fiber reinforced epoxy composites, Materials Science and Engineering: A, vol. 443, iss. 1-2, pp. 285291, 2007, doi: 10.1016/j.msea.2006.09.016

[25] V.B. Kurapati, R. Kommineni, S. Sundarrajan, Statistical analysis and mathematical modeling of dry sliding wear parameters of 2024 aluminium hybrid composites reinforced with fly ash and sic particles, Transactions of the Indian Institute of Metals, vol. 71, pp. 1809-1825, 2018, doi: $10.1007 / \mathrm{s} 12666-018-1322-\mathrm{z}$

[26] M. Bagci, H. Imrek, O.M. Khalfan, Optimization of test parameters that influence erosive wear behaviors of glass fiber - reinforced epoxy composites by using the taguchi method, Journal of Tribology, vol. 137, iss. 1, p. 7, 2015, doi: $10.1115 / 1.4028226$

[27] N. Miloradović, B. Stojanović, S. Mitrović, S. Veličković, Application of taguchi method in the optimization of zinc based composite, Proceedings on Engineering Sciences, vol. 1, no.1, pp. 104-109, doi: 10.24874/PES01.01.014

[28] M. Vasu, H.S. Nayaka, Investigation of machinability characteristics on EN47 steel for cutting force and tool wear using optimization technique, Material Research Express, vol. 5, no. 6, 2018, doi: 10.1088/2053-1591/aac67f

[29] E. Agrawal, V. Tungikar, Study on tribological properties of Al-TiC composites by Taguchi method, MaterialsToday: Proceedings, vol. 26, pp. 2242-2247, 2020, doi: 10.1016/j.matpr.2020.02.486

[30] B.P. Chang, W.H. Chan, M.H. Zamri, H.M. Akil, H.G. Chuah, Investigating the effects of operational factors on wear properties of heat-treated pultruded kenaf fiber-reinforced polyester composites using taguchi method, Journal of Natural Fibers, vol. 16, iss. 5, pp. 702-717, 2019, doi: $10.1080 / 15440478.2018 .1432001$

[31] S.J.S. Chelladurai, R. Arthanari, Investigation on mechanical and wear properties of zinc coated steel wires reinforced LM6 aluminium alloy composites by squeeze casting, Surface Review and Letters, vol. 26, no. 1, pp. 1-10, 2019, doi: 10.1142/S0218625X18501251

[32] S.J.S. Chelladurai, R. Arthanari, N. Nithyanandam, K. Rajendran, K.K. Radhakrishnan, Investigation of mechanical properties and dry sliding wear behaviour of squeeze cast LM6 aluminium alloy reinforced with copper coated short steel fibers, Transactions of the Indian Institute of Metals, vol. 71, pp. 813-822, 2018, doi: 10.1007/s12666-0171258-8 
[33] S.J.S. Chelladurai, R. Arthanari, R. Selvarajan, Investigation on mechanical properties and wear behaviour of squeeze cast LM13 aluminium alloy reinforced with copper coated steel wires, Zeitschrift für Physikalische Chemie, vol. 232, iss. 12, pp. 1787-1806, 2018, doi: 10.1515/zpch2017-1093

[34] S.J.S. Chelladurai, R. Arthanari, Effect of stir cast process parameters on wear behaviour of copper coated short steel fibers reinforced LM13 aluminium alloy composites, Materials Research Express, vol. 5, iss. 6, 2018, doi: 10.1088/2053-1591/aacd38

[35] S.J.S. Chelladurai, R. Arthanari, R. Selvarajan, T.P. Ravichandran, S.K. Ravi, S.R.C. Petchimuthu, Optimisation of dry sliding wear parameters of squeeze cast AA336 aluminium alloy - copper coated steel wires reinforced composites by response surface methodology, Internationl Journal of Metalcasting, vol. 13, pp. 354-366, 2019, doi: 10.1007/s40962-018-0258-8

[36] S.J.S. Chelladurai, R. Arthanari, Investigation on mechanical properties and tribological behaviour of stir cast LM13 aluminium alloy based particulate hybrid composites, Material Research Express, vol. 50, iss. 6, 2018, doi: 10.1088/2053$1591 /$ aacd38

[37] S.J.S. Chelladurai, R. Arthanari, A.N. Thangaraj, H. Serkar, Dry sliding wear characterization of squeeze cast LM13 / FeCu composite using response surface methodology, China Foundry, vol. 14, pp. 525-533, 2017, doi: 10.1007/s41230-017-7101-3

[38] S. Ghalme, Y. Bhalerao, M. Morgan, Optimization of load and $h B N$ content for improving tribological performance of a Si3N4-hBN ceramic composite using Taguchi-Grey relational analysis, Proceedings on Engineering Sciences, vol. 1, no.1, pp. 41-48, 2019, doi: 10.24874/PES01.01.005

[39] M. Venkatesan, K. Palanikumar, S.R. Boopathy, Experimental investigation and analysis on the wear properties of glass fiber and CNT reinforced hybrid polymer composites, Science and Engineering of Composite Materials, vol. 25, iss. 5, pp. 963-974, 2018, doi: 10.1515/secm-2017-0068

[40] R.S. Godse, S.H. Gawande, A.A. Keste, Tribological behavior of high fraction carbon steel alloys, Journal of Bio-and Tribo-Corrosion, vol. 2, iss. 3, 2016, doi: 10.1007/s40735-016-0034-3

[41] A.A. Megahed, M.A. Agwa, M. Megahed, Improvement of hardness and wear resistance of glass fiber-reinforced epoxy composites by the incorporation of silica / carbon hybrid nanofillers, Polymer-Plastics Technology and Engineering, vol. 57, iss. 4, pp. 251-259, 2017, doi: 10.1080/03602559.2017.1320724 